$17^{\text {th }}$ International Congress of Metrology, 03006 (2015)

DOI: $10.1051 /$ metrology / 201503006

(C) Owned by the authors, published by EDP Sciences, 2015

\title{
The specification, selection and use of liquid \& gas flow rate measuring devices
}

Richard Fertell

Proteus Industries Inc., 340 Pioneer Way, Mountain View, CA, 94041, USA

\begin{abstract}
Résumé. Créer une norme internationale qui est une croix - index pour tous les documents de débit reconnues et respectées dans le cadre du marquage CE ou certifié par audit d'usine pour les marques de sécurité des produits afin d'assurer que tout le liquide, gaz et GPL / GNL spécifications de la technologie de mesure de débit sont compatibles pour l'évaluation et la comparaison ainsi que de documenter et de faire progresser l'état -of-the - art de liquides technologies de mesure de débit. La norme couvrira technologies tout le liquide, gaz et GPL / GNL débit, les sources d'erreur, les applications de fluides et de température, et les incertitudes de mesure attendus. Le document standard doit être publié comme un rapport technique par le biais ASME que l'indice Cross Flow Technology visée par le Dr MJ Reader-Harris au FLOMEKO 2013.
\end{abstract}

\section{Introduction}

Which flow rate measuring technologies are appropriate for a user application? Are all flow rate device manufacturers reporting measurement uncertainty using internationally agreed upon standards?

\subsection{Problem}

In order to select and specify the correct type of flow rate measuring device(s) for an application and to compete in a level playing field, various users, industries and manufacturers would like to know the answers to the previous questions.

\subsection{Solution}

Create an international standard that lists all flow rate measuring technologies, associated error sources, fluid and temperature applications, expected measurement uncertainties and related documents. Update the standard annually to keep up-to-date with advances in technology.

\subsection{Background}

Several industries and government agencies publish liquid flow rate measuring standards specifying a single flow technology to be used in only one application. These standards are not practical for other applications and cause confusion and are misleading for users because manufacturers do not state specifications in terms of measurement uncertainty or the same type of specifications. Different technologies and, sometimes, even the same technologies cannot be compared by users because some manufacturers specify accuracy with a limited definition in footnotes that may only include instantaneous stability (repeatability).
Users need to know how flow measurement works. Flow is a dynamic process with inter-relationships between pulsating fluid, turbulence intensity, viscosity, density and primary and secondary devices. Pressures fluctuate, velocity profiles change, vortices form differently and flow-measuring devices respond differently to these changes.

\section{The International Standard}

The international standard will define flow states and related measurement discipline (liquid, solid, gas, LPG/LNG for flow and thermal plasma for Electrical) and terms not found in the VIM, such as laminar and turbulent flow. A section will describe issues that influence measurements: turbulence/cavitation and their sources, temperature effects, non-homogeneous/multistate/compressible fluids. A summary table will allow quick review of technology performance. A section will describe how each technology works, influences and a measurement uncertainty calculation. A section will describe value-added electronics outputs, specifications and measurement uncertainty contribution. A section will describe calibration method versus real use and include discussions a variety of topics that influence the quality of the unit calibration.

\subsection{Liquid Flow Terminology and Influences}

This section will describe issues that can influence measurements, such as: a) turbulence and its sources, b) cavitation and its sources, c) temperature effects on viscosity, density, device clearances, and electronics performance, d) non-homogenous fluids (multiple viscosities or densities), e) multi-state fluids of gas, liquids, solids, f) compressible fluids, g) closed/open systems and closed/open channels, h) flow ranges from 
drip/hour to Dam feed-throughs for closed channels and trickle to oceanic for open channels, as well as i) calibration method versus real use. The turbulence topic will include a discussion of the Threshold Pulsation Index (2), the Flow-Rate Correction Factor (3), and Reynold's Numbers (Re) for Laminar, Turbulent and Transition Flow Regions as well as flow profiles based upon plumbing configurations and flow velocity.

\subsection{The Summary Table}

A table shall summarize technologies by use parameters, Table 1. The table terms will be described: a) method of measurement, b) standard temperature range, c) extended temperature ranges, d) best measurement uncertainty, e) fluid compatibility, f) sensitivity to density or viscosity, g) use for liquids, gases, solids, slurries, h) Reynold's Number operating range with corresponding viscosity and density ranges.

Summary Table of Flow Technologies 


\begin{tabular}{|c|c|c|c|c|c|c|c|c|c|c|}
\hline 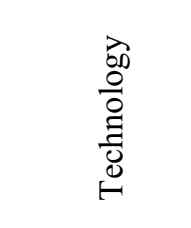 & 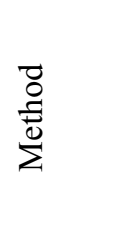 & 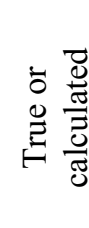 & 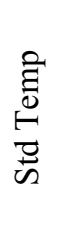 & 总 & 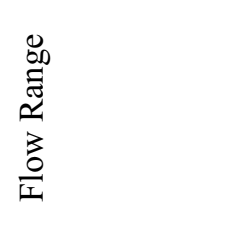 & $\sum_{\substack{\text { 岕 } \\
\infty}}^{P}$ & 总 & 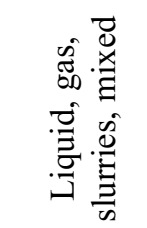 & 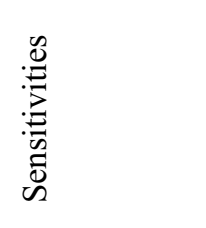 & 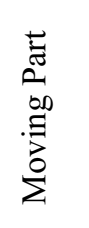 \\
\hline $\begin{array}{l}\text { Standing } \\
\text { Pipe/Weigh } \\
\text { Standard }\end{array}$ & $\begin{array}{l}\text { Volume } \\
\text { or Mass }\end{array}$ & $\Xi_{E}^{\varrho}$ & 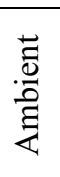 & $\begin{array}{c}-20 \mathrm{C} \\
\text { to } \\
90 \mathrm{C}\end{array}$ & $\begin{array}{c}0,12 \text { to } 38,754 \\
\text { liter } / \mathrm{min} \\
1 \mathrm{mg} / \mathrm{hr} \text { to } \\
4,000 \mathrm{~kg} / \mathrm{min}\end{array}$ & $0.025 \%$ & 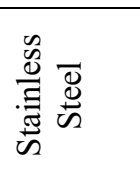 & 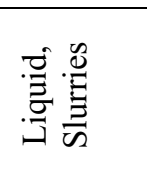 & Temperature & 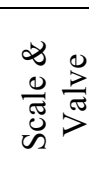 \\
\hline Coriolis & Mass & $\Xi_{E}^{\varrho}$ & $\begin{array}{l}0 \\
\frac{0}{1} \\
\frac{1}{0}\end{array}$ & $\begin{array}{l}-40 \mathrm{C} \\
\text { to } \\
200 \mathrm{C}\end{array}$ & $\begin{array}{c}0,02 \mathrm{~g} / \mathrm{hr} \text { to } \\
75 \mathrm{~kg} / \mathrm{min} \text { to } \\
4100 \mathrm{metric} \\
\text { ton } / \mathrm{hr}\end{array}$ & $\begin{array}{c}0,1 \% \text { mass } \\
0,2 \% \\
\text { volume }\end{array}$ & 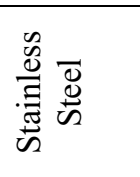 & 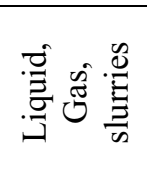 & $\begin{array}{l}\text { Density, } \\
\text { temperature }\end{array}$ & $\stackrel{0}{ٍ ٍ ~}$ \\
\hline Turbine & Volume & $\frac{\overrightarrow{0}}{\frac{\vec{J}}{\vec{J}}}$ & $\begin{array}{l}0 \\
\frac{0}{0} \\
1\end{array}$ & $\begin{array}{l}-40 \mathrm{C} \\
\text { to } \\
200 \mathrm{C}\end{array}$ & $\begin{array}{c}0,57 \text { to } 387,54 \\
\text { liter/min }\end{array}$ & $0,27 \%$ & 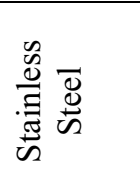 & هُ & $\begin{array}{c}\text { Turbulence, } \\
\text { flow profile, } \\
\text { viscosity, } \\
\text { temperature }\end{array}$ & 苛 \\
\hline $\begin{array}{l}\text { Orifice } \\
\text { Plate }\end{array}$ & Volume & $\frac{\overrightarrow{0}}{\frac{\tilde{J}}{J}}$ & $\begin{array}{l}0 \\
0 \\
\frac{1}{1} \\
\end{array}$ & $\begin{array}{c}-20 \mathrm{C} \\
\text { to } \\
100 \mathrm{C}\end{array}$ & $\begin{array}{c}0,57 \text { to } 378,54 \\
\text { liter/min }\end{array}$ & $1 \%$ & 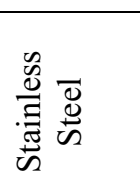 & : & $\begin{array}{c}\text { Turbulence, } \\
\text { flow profile, } \\
\text { viscosity, } \\
\text { temperature }\end{array}$ & 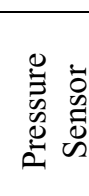 \\
\hline Target & Volume & $\frac{\overrightarrow{0}}{\frac{\tilde{J}}{\bar{J}}}$ & $\frac{0}{o}$ & $\begin{array}{l}0 \mathrm{C} \text { to } \\
70 \mathrm{C}\end{array}$ & $\begin{array}{l}0,57 \text { to } 378,54 \\
\text { liter/min }\end{array}$ & $3 \%$ & 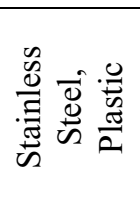 & 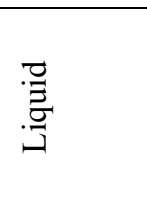 & $\begin{array}{l}\text { Turbulence, } \\
\text { flow profile, } \\
\text { viscosity, } \\
\text { temperature }\end{array}$ & 告 \\
\hline $\begin{array}{c}\text { Variable } \\
\text { Area } \\
\text { (rotameter) }\end{array}$ & Volume & $\frac{\bar{d}}{\frac{\tilde{J}}{J}}$ & $\frac{0}{0}$ & $\begin{array}{l}0 \mathrm{C} \text { to } \\
70 \mathrm{C}\end{array}$ & $\begin{array}{c}0,57 \text { to } 378,54 \\
\text { liter/min }\end{array}$ & $3 \%$ & 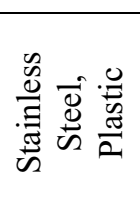 & 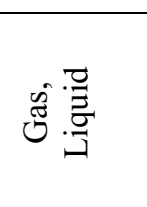 & $\begin{array}{l}\text { Turbulence, } \\
\text { flow profile, } \\
\text { viscosity, } \\
\text { temperature }\end{array}$ & $\frac{\vec{E}}{I}$ \\
\hline $\begin{array}{c}\text { Thermal } \\
\text { differential }\end{array}$ & Volume & $\frac{\vec{d}}{\frac{\vec{J}}{\vec{J}}}$ & $\frac{0}{0}$ & $\begin{array}{l}0 \mathrm{C} \text { to } \\
70 \mathrm{C}\end{array}$ & $\begin{array}{c}0,57 \text { to } 378,54 \\
\text { liter/min }\end{array}$ & $2 \%$ & 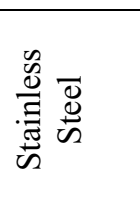 & 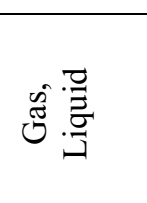 & $\begin{array}{c}\text { Turbulence, } \\
\text { flow profile, } \\
\text { viscosity, } \\
\text { temperature }\end{array}$ & \\
\hline $\begin{array}{c}\text { Pressure } \\
\text { differential }\end{array}$ & Volume & $\frac{\overrightarrow{0}}{\frac{\pi}{\pi}}$ & $\begin{array}{l}0 \\
8 \\
\vdots \\
0\end{array}$ & $\begin{array}{l}0 \mathrm{C} \text { to } \\
100 \mathrm{C}\end{array}$ & $\begin{array}{c}0,57 \text { to } 378,54 \\
\text { liter/min }\end{array}$ & $1 \%$ & 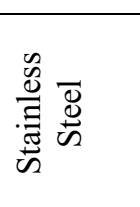 & 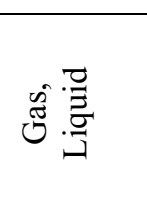 & $\begin{array}{l}\text { Turbulence, } \\
\text { flow profile, } \\
\text { viscosity, } \\
\text { temperature }\end{array}$ & 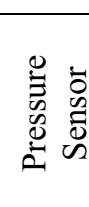 \\
\hline Ultrasonic & Volume & $\frac{\frac{\vec{d}}{\pi}}{\frac{\pi}{\bar{J}}}$ & $\frac{0}{0}$ & $\begin{array}{l}0 \mathrm{C} \text { to } \\
70 \mathrm{C}\end{array}$ & $\begin{array}{c}0,57 \text { to } 378,54 \\
\text { liter/min }\end{array}$ & $\begin{array}{c}0,2 \% \\
\text { multi-beam } \\
2 \% \text { strap- } \\
\text { on }\end{array}$ & 咅窟 & 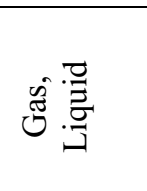 & $\begin{array}{c}\text { Turbulence, } \\
\text { flow profile, } \\
\text { viscosity, } \\
\text { temperature }\end{array}$ & \\
\hline Magnetic & Volume & $\frac{\overrightarrow{0}}{\frac{0}{\tilde{J}}}$ & $\frac{8}{2}$ & $\begin{array}{l}0 \mathrm{C} \mathrm{t0} \\
70 \mathrm{C}\end{array}$ & $\begin{array}{c}38,75 \text { to } \\
378,54 \\
\text { liter/min }\end{array}$ & $1 \%$ & 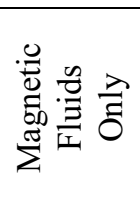 & : & $\begin{array}{c}\text { Non- } \\
\text { magnetic } \\
\text { fluid }\end{array}$ & \\
\hline Gear & Volume & $\Xi_{E}$ & $\begin{array}{l}0 \\
\substack{n \\
o}\end{array}$ & $\begin{array}{l}0 \mathrm{C} \text { to } \\
75 \mathrm{C}\end{array}$ & $<17,4$ litre/min & $1 \%$ & 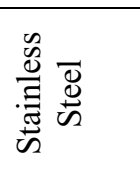 & 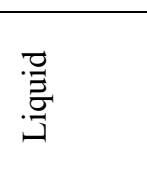 & $\begin{array}{c}\text { Viscosity } \\
<2 \mathrm{cP}\end{array}$ & 节 \\
\hline $\begin{array}{c}\text { Vortex } \\
\text { shedding }\end{array}$ & Volume & 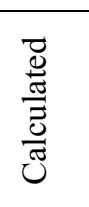 & $\begin{array}{l}0 \\
\frac{n}{1} \\
0\end{array}$ & $\begin{array}{l}0 \mathrm{C} \text { to } \\
75 \mathrm{C}\end{array}$ & $\begin{array}{c}0,57 \text { to } 378,54 \\
\text { liter/min }\end{array}$ & $1 \%$ & 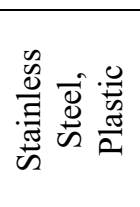 & 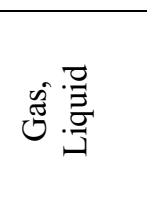 & $\begin{array}{c}\text { Turbulence, } \\
\text { flow profile, } \\
\text { viscosity, } \\
\text { temperature }\end{array}$ & 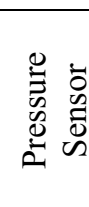 \\
\hline
\end{tabular}


single viscosity is $0,27 \%$ of reading with a fluid and

\begin{tabular}{|c|c|c|c|c|c|c|c|}
\hline Error Source & Type & Contribution & Distribution & Divisor & $\begin{array}{l}\text { Contribution } \\
\text { divided by } \\
\text { Divisor }\end{array}$ & $\begin{array}{l}\text { Sensitivity } \\
\text { Coefficient }\end{array}$ & $\begin{array}{l}\text { Squared } \\
\text { contribution } \\
* \text { Sensivity }\end{array}$ \\
\hline $\begin{array}{l}\text { Turbine Meter Repeatability (in a } \\
\text { single viscosity) }\end{array}$ & $\mathrm{A}$ & 0,05 & Statistical & 1 & 0,05 & 1.0 & $\begin{array}{l}0,0025 \\
\mathrm{U}_{\mathrm{a}}\end{array}$ \\
\hline Cal Lab Flow Stand - Flow Rate & $\mathrm{B}$ & 0,05 & Rectangular & 1,732 & 0,029 & 1.0 & $\begin{array}{l}0,0008 \\
\mathrm{U}_{\mathrm{b}}\end{array}$ \\
\hline Cal Lab Flow Stand - Frequency & $\mathrm{B}$ & 0,00 & Rectangular & 1,732 & 0,00 & 1.0 & $\begin{array}{l}0,0000 \\
\mathrm{U}_{\mathrm{b}}\end{array}$ \\
\hline $\begin{array}{c}\text { Cal Lab Master Temperature } \\
\text { Probe }(+/-28 \mathrm{C})\end{array}$ & $\mathrm{B}$ & 0,00 & Rectangular & 1,732 & 0,00 & 1.0 & $\begin{array}{l}0,0000 \\
\mathrm{U}_{\mathrm{b}}\end{array}$ \\
\hline $\begin{array}{l}\text { Viscosity Measurement (or table } \\
\text { calculation) }\end{array}$ & $\mathrm{B}$ & 0,25 & Rectangular & 1,732 & 0,144 & 1.0 & $\begin{array}{l}0,0207 \\
\mathrm{U}_{\mathrm{b}}\end{array}$ \\
\hline $\begin{array}{l}\text { Density, no need to calculate from } \\
\text { base density; }<7 \text { bar, pressure } \\
\text { effects are }<0.01 \% \text { of reading }\end{array}$ & $\mathrm{B}$ & 0,00 & Rectangular & 1,732 & 0,00 & 1.0 & $\begin{array}{l}0,0000 \\
\mathrm{U}_{\mathrm{b}}\end{array}$ \\
\hline Standard Error Estimate (SEE) & $\mathrm{B}$ & & & & & & \\
\hline Strouhal No. Calculation & $\mathrm{B}$ & & & & & 1.0 & \\
\hline Roshko No. Calculation & $\mathrm{B}$ & & & & & 1.0 & \\
\hline Interpolation Error & $\mathrm{B}$ & & & & & & \\
\hline $\begin{array}{l}\text { Piping/Inlet Mismatch (difference } \\
\text { between pipe inner diameter and } \\
\text { unit inlet diameter) }\end{array}$ & $\mathrm{B}$ & & & & & & \\
\hline
\end{tabular}

\subsection{Technologies}

This section describes how each technology works, influences and a measurement uncertainty calculation. Coriolis, turbine, orifice plate, target, variable area (rotameter), thermal differential, pressure differential, ultrasonic, magnetic, gear, vortex shedding and other technologies are covered. The Turbine Technology Section is an example.

\subsubsection{Turbine Technology}

A turbine measures volumetric flow rate based upon the rotational speed of a bladed wheel. The rotating wheel is sensitive to the viscosity of the fluid because the force of the fluid transferred to the wheel is dependent upon how much of the fluid slips by the blades. A low viscosity liquid will not transfer as much fluid force to the blades of the wheel as a higher viscosity fluid. A change in temperature of $5 \mathrm{C}$ can cause a $0,1 \%$ change in the reported flow rate measurement.

A compensation equation is used to predict turbine meter behaviour based upon temperature and viscosity. The compensation equation uses dimensionless Reynold's numbers (Roshko and Strouhal) that take into account the expansion effects of materials based upon temperature. It is important to have at least three viscosities characterized for the use range to verify the turbine meter behaves as predicted. Unless requested, turbine meter behaviour is generally measured for only one viscosity.

With a 7:1 range ratio of low to high flow rate, the best measurement uncertainty of a turbine meter on a ambient air temperature stable within $+/-2 \mathrm{C}$.

\subsubsection{Equations}

A turbine measures All symbols used in equations will be defined in the Standard. Expanded measurement uncertainty is expressed using equation (1):

$U_{e}=2 \sqrt{U_{a}^{2}+U_{b 1}^{2}+U_{b 2}^{2}+\ldots+U_{b n}^{2}}$

The pulsation index is defined by equation (2):

$$
I_{p}=\frac{\left(\overline{V_{f}}\right)_{\max _{f}}-\left(\overline{V_{f}}\right)_{\min }}{2\left(\overline{V_{f}}\right)_{a v g}}=\frac{\left(q_{v}\right)_{\max }-\left(q_{v}\right)_{\min }}{2\left(q_{v}\right)_{a v g}}
$$

The flow-rate correction factor, based upon the pulsation index, is defined by equation (3):

$$
F_{p}=\frac{\text { indicated_flow }}{\text { average_flow }}=\left(1+4 \alpha b_{p} I_{p}^{2}\right)^{n}
$$

An axial flow meter compensation equation is based upon a Strouhal Number, equation (4), and a Roshko Number, equation (5). 
$S_{r}=\frac{f}{u} c^{3}$

$$
R_{o}=S_{t} R_{e}=\frac{f L^{2}}{v}
$$

A coriolis mass flow meter is described in equation (6):

$$
\dot{M}=S_{k} \frac{A_{c}}{A_{e}}\left(\frac{1}{f_{v}}\right)
$$

\subsubsection{Electronics outputs and Uncertainty}

This section describes electronics used in addition to the primary mechanical/electrical transducer element and the extra contribution of error to the measurement uncertainty calculation.

The additional output electronics adds value to the primary element signal, such as: a) producing a scaled voltage from a frequency, b) compensating for temperature or viscosity or density, c) dampening flow pulsations, d) producing a communications port signal, to mention a few. The additional electronics can usually be remote-mounted because the value added electronics are typically more sensitive to extreme environmental conditions than the primary sensing technology.

\subsubsection{Calibration Method and its Quality}

This section describes the calibration method versus real use and includes discussions on a variety of topics that influence the quality of the unit calibration. The calibration shall be in an environment as close as possible to the intended use of the flow measurement instrument, as per the Laboratory Management Standard ISO 17025. The flow points and number of flow points shall be selected based upon the use of the flow measurement instrument. The inlet plumbing shall be the plumbing attached to flow measurement instrument when used. The length and configuration of inlet plumbing to the unit under calibration shall conform to the turbulence influences stated in the technology section of this standard, such as a length of $1,10,100$ or 1000 times the pipe inner diameter. The fluid viscosity, density and temperature shall be within an acceptable tolerance range for the use of the flow measurement instrument. The fluid used in calibration may be substituted with fluids of like fluid properties in order to ensure the safety of the personnel performing the calibration and be compatible with the calibration system as well as reduce the cost of the calibration. A 4:1 ratio of calibration system versus unit under calibration shall be maintained, whenever possible, to ensure the integrity of the calibration measurement uncertainty maintains less than a $2 \%$ producer's risk of false acceptance. The fluid temperature shall be measured at the unit-undercalibration as well as the calibration references because mass flow and volumetric flow are not conserved. In some circumstances, the calibration must be performed in situation, such as flow measurement instruments used in pipelines for water or petroleum as well as in rivers and oceans.

\section{Conclusion}

Per discussions at the FLOMEKO 2013 conference, this document will be first issued through ASME, then issued through ISO as a Technical Report. Dr MJ Reader-Harris calls this document the "Cross-Index" because related International Documents are referenced in each technology section.

\section{Acknowlegements}

Thanks for the encouragement to continue writing this standard to Dr MJ Reader-Harris, Jon Heiner and, especially, Gerri Field, my wife.

\section{References}

1. W.G. Andrew, Applied Instrumentation in the Process Industries Volume 1: A Survey (Gulf Publishing Company, Texas, 1974)

2. R.W. Miller, Flow Measurement Engineering Handbook (McGraw-Hill, New York, 1996).

3. W. Guthrie and Hung-kung Liu, Hands-on Workshop on Estimating and Reporting Measurement Uncertainty, NCSLI Conference, pp. 7-107 (St. Paul, Minnesota, USA, March 2008).

4. ISO/TAG 4/WG 1, Guide to the Expression of Uncertainty in Measurement (International Standards Organization, Geneva, 1993)

5. L.O. Olsen, Introduction to Liquid flow Metering and Calibration of Liquid Flowmeters, National Bureau of Standards Technical Note 831 (NIST, USA, 1974)

6. ISO/IEC 17025:2005, General requirements for the competence of testing and calibration laboratories (International Standards Organization, Geneva, 2005)

7. Haefelfinger, Honegger, Gfeller, A Novel Concept of a High Accuracy Calibration Rig, (14 ${ }^{\text {th }}$ Congres International de Metrologie, Paris, France, 22-25 Juin 2009)

8. Christopher David and Pierre Claudel, Novel Water Flow Facility in France Range Extension to Low Flow Rates $(10000 \mathrm{ml} / \mathrm{h}$ down to $1 \mathrm{ml} / \mathrm{h})$, MAPAN - Journal of Metrology Society of India, Vol. 26, No. 3, pp. 203-209 (2011)

9. ASME MFC-11-2006, Measurement of Fluid Flow by Means of Coriolis Mass Flowmeters, (ANSI, USA, 2014)

10. ISO 11631:1998(E), Measurement of fluid flow Methods of specifying flowmeter performance (International Standards Organization, Geneva, 1998)

11. ISO 9368-1:1990(E), Measurement of liquid flow in closed conduits by the weighing methodProcedures for checking installations - Part 1: 
Static weighing systems (International Standards Organization, Geneva, 1990)

12. ISO 5168:2005(E), Measurement of fluid Procedures for the evaluation of uncertainties (International Standards Organization, Geneva, 2005)

13. ISO 4185-1980(E), Measurement of liquid flow in closed conduits - Weighing method (International Standards Organization, Geneva, 1980)

14. ANSI/NCSL Z540.3-2006, Requirements for the Calibration of Measuring and Test Equipment (ANSI, USA, 2006) 